\title{
Sciendo
}

DOI: $10.2478 /$ aa-2019-0001

\section{The motifs of happiness, distress, anger and misery in the tales of Magda}

\section{Szécsi}

Gizela Tóthová

Gizela Tóthová is a researcher of Roma literature at the Institute of Hungarian Linguistics and Literary Science, Constantine the Philosopher University in Nitra, Slovakia. At present she is completing her $\mathrm{PhD}$ thesis on the topic: "Roma tales in education". Her research focuses on the functions of primary socialization and types of intra- and extra-familiar interaction, which are illustrated via several examples in the presented study. The study itself deals with the motifs of happiness, anxiety, anger and misery appearing in Roma tales.

\begin{abstract}
The present study focuses on the tales of Hungarian-Roma writer Magda Szécsi, which were studied using the content analysis method. This study constitutes part of a larger research project that aims to provide methodological guidance for the integration of Roma pupils in schools that use Hungarian as the language of instruction. The types of function of primary socialization and the types of intra- and extra-familial interaction are illustrated via examples in the study. The motifs of happiness, anxiety, anger and misery in the tales of Magda Szécsi's two books, Madarak aranyhegedün (Birds on the Golden Violin [1996]) and Az aranyhalas lószem tükre (Mirror of the Horse Eye with the Gold Fish [1988]), are analysed in light of the aforementioned aspects. I applied the research method of qualitative content analysis and explained the forms of happiness and unhappiness in the books. There are many examples in the tales under discussion of the conditions of happiness and the reasons for misery in Roma culture. The three components determining the characters' happiness or unhappiness are faith in God, idolatry and Gypsy law.
\end{abstract}

\section{Introduction}

I should like to point out at the outset why I deal with Roma literature in this paper: the topic of my first thesis was Roma traditions and superstitions (Tóthová, 2012, pp. 227-238) and of my second thesis Roma superstitions (Tóthová, 2014, pp. 71-81). I carried out field research for both theses; I visited Roma families to conduct interviews with them. My research led me to realize that the majority of the interviewees not only had trouble defining their own identity but were even unaware of certain elements of Roma culture. I encountered the same "problem" sometime later when teaching at a primary school using Hungarian as language of instruction, where more than $90 \%$ of school pupils were of Roma origin. Therefore, the aim of my doctoral 
thesis is to gain a better knowledge of Roma culture and to promote the inclusion of Roma culture in the curriculum of primary schools that use Hungarian as language of instruction in Slovakia. This study aims to present part of my doctoral thesis research in which literary tales written by authors of Roma origin are analysed. First, family socialization, interactions within and outside of the family and the characters and roles of family members in the tales are explained; then, the motifs of happiness, distress, anger and misery are described. Magda Szécsi's literary tales in her two books Madarak aranyhegedün (Birds on the Golden Violin [1996]) and Az aranyhalas lószem tükre (Mirror of the Horse Eye with the Gold Fish [1988]) are analysed in the present study (Tóth, 2018, pp. 173-180). Magda Szécsi is a Hungarian writer of Roma origin.

Péter Bálint stressed an important aspect in his book Archaic Images in Folk Tales, namely that a kind of support or foothold should be provided for Roma people struggling to find their own place in contemporary European societies due to modernization and globalization processes (Bálint, 2014, p. 213). We therefore consider Roma tales to perfectly fit that purpose. The present study is not intended to give concrete methodological examples; rather it aims to point out how the analysed motifs are reflected in the tales and touches on Roma cultural elements.

\section{Methodology}

The analysis is based on quantitative research methods: the methods of textual analysis and content analysis. The first scientific definition of content analysis was formulated by Bernard Berelson (1952); according to his definition, content analysis is "a research technique for the objective, systematic and quantitative description of the manifest content of communication" (Móré, 2010, pp. 47-52). Lehota (2001) focuses on a three-phase content analysis; as the system of categories to be analysed may be broadened during the study, modern content analyses thus only evaluates on the basis of qualitative terms:

a) The first step in analysis is to code the text into coding categories that are not pre-defined but determined during the course of analysis.

b) The next step is to analyse, i.e. to map recurrences and co-occurrences in the text.

c) The third step is to interpret tendency-like co-occurrences and to identify textual patterns.

This method permits the detection of the existence of hidden information that is not explicitly formulated but hinted at (Móré, 2010, pp. 53-64). Klaus Krippendorff (1995) does not agree with the view that content analysis is nothing but the enumeration of each category, instead he proposes focusing on the purpose of analysis and on the mapping of symbolic meanings. The 
method of content analysis is not intended to interpret content but rather messages that can be considered as content in the given system. Consequently, the system changes and so does the meaning. The analysis is based on Krippendorff's method (Krippendorff, 1995, pp. 21-23).

Family socialization, interactions within and outside of the family, characteristics of family members and relations outside the family in the tales under discussion

Clarification of the definition "primary socialization" was the first step in examining the functions of primary socialization (socialization in the family). There is a direct link between the processes of acquisition of social experiences, cultural knowledge, linguistic knowledge and language usage. The process of primary socialization is partly the result of language acquisition and learning of the rules governing language arrangements, the components of which are certain elements of social and human relationships, behaviour patterns, manner of speech, values, beliefs, superstitions, and customs specific to a given community (Réger, 1990, p. 88). Tamás Kozma considers the oldest and most enduring human institution, the family, as the most important agent of primary socialization (Kozma, 2001). Giddens supplements this definition with the findings of the latest research and extends the category of nuclear family to the whole symbolic family (Giddens, 2000, p. 64; Giddens, 2009, p. 39). An individual makes decisions and choices, which form the backbone of subjective changes, as a member of the symbolic family. The symbolic family "conveys a constantly changing image of the family, which forms an intricate pattern that reflects the social environment and the characteristics of the individual and the family through life courses, lifestyles, and social patterns. Socialising functions take place, in terms of time and space, in the symbolic family based on knowledge and myths absorbing family history stories" (Boreczky, 2007, p. 17). Child-rearing approaches allow for the drawing of secondary conclusions, which highlight similarities and differences comparable to the socialization patterns of the majority society. The downside of these conclusions is that they evaluate socialization in the family against the patterns expected by the majority society; institutions and actors that play a role in the process of socialization are thus ignored (Károlyi, 2009, p. 146). Socialization in the family not only means biological and personality development but also provides behaviour patterns and role models, which occur and are strongly reflected in the tales under discussion. As a result of socialization, not only are adaptability skills developed but also the culture of the society, which is a vehicle for standards of social contact and cooperation, is passed down. 


\section{Interactions within the family}

A core element of the tales under discussion is the so-called symbolic family (the whole camp), not family in the narrower sense.

The Gypsy family model in the tales has the following characteristics: Gypsy characters, who are, in most cases, members of a Gypsy "cumpania", live in an isolated Gypsy camp on the outskirts of forests, far from the villages of the majority society; characters lead lives of quiet desperation; they are looking to find their place and want to find the idyllic Land of the Gypsies; in the tales there often occur the motifs of wandering and persecution; the already settled Gypsies have to strike out under some kind of strong external pressure; indignity, hopelessness and social exclusion are features of their everyday lives.

\section{New-borns in the tales}

Childbirth is of great importance in the tales and an important event in marriage; it is thus an important component of the tales under discussion. The protagonist in the tale Birds on the Golden Violin is also conceived miraculously. Her mother drinks the sweet dew of mountain trees and brings a prodigious child, Hanidzsa, into the world:

At the moment of Hanidzsa's birth hundreds of stars fell upon the earth, turned into golden serpents and then crawled into the camp fire. The fire threw up golden sparks, from which millions and millions of dazzling pearls scattered upon the ground and over the tents, horses, and the whole Gypsy camp. They were knee-deep in the cascade of pearls. The brightest pearl hatched, and a beautiful fairy, with a golden violin under her arm, popped out of it. She started singing so heartbreakingly beautifully that all that heard her singing shed tears shinier than pearls. Liellara also heard the singing and her heart was filled with love for her people, because God sent the miracle to her people, not others, to take the lines of sorrow and fear out of their faces. Gypsy law is the law of fear and invention of fear, she thought as she looked at her daughter and had no fear of the morning. (Szécsi, 1996)

There are two extreme poles of miraculous conception in the tales: the child either possesses abilities due to which (s)he almost wipes out the whole cumpania, or miracles follow the birth of the child, who can heal sick Gypsies (e.g. Hanidzsa). Children are usually born within the bond of matrimony, and the birth of a child gives the parents great joy. Parents never differentiate among sons and daughters; they take as much delight in the birth of a female child as in the birth of a male child. In the story of King of the Gypsies, the husband is so happy about becoming a father that "he distributed handfuls of gold, silver, and every sort of precious stone to his people with joy. The Gypsy camp shone brighter than the sun” (Szécsi, 1988). 
The motif of the cruel child can also be found in the tales (The Mysterious Szalizáti), Szalizáti is born with magic abilities: he not only sees others' thoughts but can also speak right after his birth. After her mother dies on the spot with astonishment, his father wants to run his son out of the tent, "but as soon as he touched him, he burnt into ashes in an instant. The little boy sprinkled the white ash remains of his father onto his palm, blew them and watched, laughing, as what had once been hands, feet, and eyes that had moved, sensed and been alive in the sweetscented tent a second ago filled the air" (Szécsi, 1988). The motif of incest occurs in the tale King of the Gypsies, in which a father marries his own daughter because of the lie of a voivode ('chieftain'), and later learns the truth from an elderly, dying woman (Szécsi, 1988).

\section{Family members as role models}

The father figure in the tales under discussion is either positive (of which fewer examples exist) or negative. In the case of a negative father figure, the father keeps his tribe's customs and expectations firmly in mind. In the story of Trebla and Rebeka, the father buys and gives his daughter everything she wants. One day his daughter commands her father to pull off the wings of the son of the King of the Wind. The merchant grants her request without hesitation. Justice prevails in this tale as well, as the merchant and his daughter pay the price for their crimes (Szécsi, 1988). The tales help their readers to appreciate quickly the customs of Gypsy tribes.

In the tales, often a father chooses a husband for his daughter, and the daughter never has a say in this. In the tale Birds on the Golden Violin, the voivode wants to give his daughter's hand to the Prince of Wicked Hells, as his people will be given eternal life and eternal wealth in exchange for the girl. The same tale paints a clear picture of the gender roles of men and women within a tribe: men's jobs are to take care of horses, chase women and revel, while women work hard for men from morning till night (Szécsi, 1996, Tóthová, 2018).

There are positive mother figures in most of the tales. A mother's job is to take care of her family. When a man is made a widower, he never looks for a new wife, and a surrogate mother takes the mother's place. The tales lack the motif of the wicked stepmother, and surrogate mothers always take care of children as if they were their own. Mother characters often become sick with worry about their children. Unfaithful mother figures appear repeatedly in the tale Birds on the Golden Violin. An enchanted Gypsy boy tells one such story: the boy's mother abandoned her people and went to join a lake monster, by whom she had the boy who is telling the story. As the boy had webbed fingers and toes, his mother also chose to abandon him (Tóthová, 2018, p. 177). 
The tales under discussion also refer to the role of Gypsy women and girls. In the story of Karadana's Curse, we learn that a Gypsy girl has been promised to the only son of the voivode of the Gypsies even before she was born, and she must obey her husband and bring many children into the world (Szécsi, 1988). In the tale Birds on the Golden Violin, a surrogate mother reproaches a girl for running away: "I understand that you hope for more than being the wife of the voivode's son, but you stabbed me with your words. Thinking about the world is what men do, and we women must accept our fate with humility. We ought to renounce our desires when losing our milk teeth to avoid trouble. Bear several children with night-black eyes, and you'll see your husband will respect you, you'll see you will be happy, and your dreams will remain lucid" (Szécsi, 1996).

\section{Intra-familial relationships}

There are many different types of intra-familial and intra-tribal relationships in the tales. In the tale King of the Gypsies, when it turns out that a father has fallen in love with his own daughter, he swears bloody revenge against his people (Szécsi, 1988). An important requirement for the members of Gypsy tribes is that they all must respect Gypsy law. In the tale Birds on the Golden Violin, a husband kills his wife, Radazána, because she broke the law and let her own brother-in-law into her tent.

A positive example of extra-tribal marriage can be found in the same tale, when the father picks a husband from another tribe for his daughter to bring the two Gypsy tribes closer to each other (Szécsi, 1996).

\section{Spouses}

In the tales under discussion, only women are required to be faithful to their husbands, and even though spouses are closely bonded and devoted to each other, husbands can sleep with other women as well. If a wife is unfaithful, the circle of elders meets to pass sentence upon her. In the tale King of the Gypsies, a prime example of conjugal love is when the husband is so devastated by his wife's death that his hair turns white with the news and never leaves his tent for a year after the funeral (Szécsi, 1988). In the story of Birds on the Golden Violin, Hanidzsa's surrogate mother tells us how unhappy she was in her marriage: "Happy? What is happiness, my child? I remember tears turning dark from the fear on my face and barren women's shivering nights as our red eiderdowns were fading like the love I never had. I was always alone! Grass lily, the flower of hate, blew in our quiet tent. Yes, perhaps I should have fled. I've lived a full 77 years, my child, but I never encountered happiness. I stole tiny bits of 
others' happiness and hid them to admire them. Your laugh has warmed my old bones, scaring death away" (Szécsi, 1996, Tóthová, 2018).

\section{Children}

Gypsy children usually have respect for and cling to their parents. What their father says goes, and children must never disobey their father. In the tale Birds on the Golden Violin, a Gypsy voivode and his two sons set off to find the Prince of Hells to sell his daughter to him. The two sons disagree with their father's intentions but do not really have a choice other than to obey him. The daughter protests, to no avail, because her father's will is supreme, and she must never transgress it: "How could a man like him possibly love his people, a man who doesn't love his own child, who sells his daughter, who is unconcerned by the future happiness of his own flesh and blood? He would even be a traitor to his people if he had to, even though he plays the hero," Razsinnáta says bitterly. Her surrogate mother tries to comfort her by telling her that very few Gypsy women marry for love (Szécsi, 1996).

In the tale The Gypsy Woman and the Devil, a poverty-stricken mother loves her 13 sons so much that she goes on a quest to collect food for them. "They were so poor that they slept as much as they could from sunrise to sunset so that they would not be tormented with hunger. Sorrow ate at Vunida's heart when she looked at her skeletal sons." While on her quest for food the devil casts a spell on the woman, and her sons look for their mother in the world and do not know that the sour cherries they are eating are the fruit of their mother's body (Szécsi, 1988).

\section{Extra-familial relationships}

The fact that Gypsy characters fear strangers and warn the other members of their tribe against them sums up extra-familial interactions in the tales. When Hanidzsa wants to leave her tribe, her surrogate mother warns her not to go because no man of the tribe has ever crossed the mountains or ventured among strangers. Hanidzsa wants to leave her tribe, see the world, meet new people and find happiness. An example of the enmity between tribes can also be found in the same tale, when the young voivode of the Mohála tribe is found in Razsinnáta's tent. There has been bad blood between the two tribes for decades, even though they do not know what the original cause of the feud was, since even the eldest cannot remember it (Szécsi, 1996).

The story of The Orphan Radazána is a good example of reaching out, in which the king lends weary strangers dressed in dirty, torn clothing a helping hand by allowing them to settle in his forest. One of the soldiers attempts to defy the king's will, as he does not want the Gypsies to settle in their land, because one of the fortune tellers had dreamt that the Gypsies were going 
to bring unhappiness upon the king. The motif of groundless cruelty also occurs in the tale, when the king, standing in the middle of the Gypsy camp, orders his men to rip their tents to shreds and to throw a man into the fire. Jealousy caused him to throw the Gypsy man into the fire and to drive his wife to her death: "Then Radazána came out from where she had been lurking behind the tree and ran straight into the fire, ran into Szóberjáni's trembling arms. They held each other tight, ignoring the destructive power of the flames, and waited for the fire to make them one forever" (Szécsi, 1988). The deed of the protagonist of the tale King of the Gypsies is justified, as a dying old woman tells him that he married his own daughter and everyone in the camp had already known about it but him. Kartu swears bloody revenge against his people, and the inhabitants of the camp are all terrified of him. He comes up with impossible tasks, "because it was the only way he could find reasons to justify whipping the people to death with his own two hands" (Szécsi, 1988).

There is always a reason for cruelty in the tales under discussion. Although the sinner is always punished, cruel acts are not always a series of acts performed in a consistent manner; some of the sinners in the tales only partially succeed in their mission. Cruel acts are committed either by the wicked, for which they will be punished later in some cases, or by the hero in order to beat the wicked.

\section{Forms of happiness, distress, anger and misery}

\section{Motifs of happiness in the tales}

The stories are marked by misery. Gypsy women are rarely happy and are often forced into marriage against their will. Hanidzsa's parents love each other with true love, and she declares when facing justice: "I know I'm going to die, but I shall be happy to go to my death. I'll give birth to a child to Rodákosán's delight and comfort. I'm a woman, that's what I'm supposed to do. To make my husband happy at any cost [...]” (Szécsi, 1996).

Non-Gypsy husbands dote on their wives: "Sambradi-Koa-Hokk was the happiest of men. They organised an elaborate wedding celebration, which was well known far and wide. Goldenhaired people worshipped Hanidzsa as a goddess for her fascinating beauty. Gypsy caravans, one after the other, came to the king's domain, where they could settle down in peace thanks to Hanidzsa. But Hanidzsa was unhappy. She wasn't happy unless she, in shabby clothing, in disguise, snuck out of the bleak castle and went to the Gypsy camp on the edge of the town, where she reverted to being the child as she listened quietly to old Gypsy tales and admired her people dancing" (Szécsi, 1996). 
In one of the tales, a newlywed Gypsy bride gives the following response to the question whether a Gypsy woman loves her husband: "I'll come to love him," Rubekka said in a low voice, thinking about Brohk, the blacksmith's 20-year-old handsome son, but she wouldn't have said his name for the world" (Szécsi, 1996). Hanidzsa's mother did not marry the king for love either: "Zsijegsán was the only one I truly loved, yet I married your father, because my handsome Gypsy man had married someone else" (Szécsi, 1996). Hanidzsa's daughter hits the road with the members of a strange Gypsy tribe to find true happiness. She vows to herself that she will get married only if she loves her chosen with true love. The golden violin, patron saint of the mother and the daughter, warns Razsinnáta: "You're living among strangers, not your people. You have to find your own people, because you can find true happiness only among yours" (Szécsi, 1996). By the time Razsinnáta goes back to her tribe, Gypsy law has been abolished, strangers have merged into her tribe and started families with her people. Dzsaharla, the eldest woman of the tribe, warns her people that if they do not follow their old laws, God will punish them. Their happiness was not to last; an instant later the whole camp is in flames, and grown-ups and children burn along with their tents. The surviving strangers flee, nothing remaining of the children. Razsinnáta knows that happiness will come only if she chooses a husband from her own tribe. A short while later, she chooses a mate for herself: "Zsijegsán and Razsinnáta lived in blissful happiness and peace. They were soon blessed with a child, and the child was born on a winter night. Zsijegsán was happy and felt thankful” (Szécsi, 1996).

\section{Distress}

Stranger anxiety, the fear of God and of Gypsy law cause distress to the characters of the tales. Hanidzsa says when her surrogate mother cautions her not to go among strangers: "Here, too, I feel like a stranger. "My people only like me because I'm useful. I don't want to die without knowing what happiness is. I don't want your life! I'm going to leave at dawn tomorrow. Though I don’t know where to go" (Szécsi, 1966).

In the tale Karadana's Curse, Gypsies expel the protagonist's mother because she is a witch. She gives birth to a baby girl. Before her death, she tells her daughter to return to her tribe when she turns 16. Before leaving, the girl performs various superstitious rituals, as she fears that if she does not do so some misfortune will befall her in her new family. "She swept her little shack, but she always swept dust into the dustpan in front of the mirror to prevent the devil from queering her luck. She milked Rupi, the goat, but, after milking, she splashed a mug of milk toward the sun to stay beautiful. She wove a flowing dress of cobwebs, which then she 
dyed red with her own blood to avoid illness. Before going to her bed made of grass, she put the broom at the door to keep evil spirits away" (Szécsi, 1988).

In the story of Birds on the Golden Violin, Hanidzsa fears her deceased father's ghost coming back and therefore covers the mirror with black cloth and rips her clothes in her sorrow. The motifs of Gypsy idols and animal sacrifice occur in the same tale. When the Gypsy idol is broken in two and burnt, the characters fear God's punishment, so they sacrifice black cocks to God to drive away wraiths. "If our lives are filled with sorrow and fear, our tales should at least be merry, Hanidzsa bowed her head and immediately fell into a deep sleep" (Szécsi, 1996).

\section{Anger}

An important element of the tale King of the Gypsies is intra-tribal hatred. The voivode hates his son-in-law, and, while he is away, the voivode kills everybody who knows the son-in-law. "The Gypsy camp was full of the putrid stench of hanged men's decaying flesh. Black tents faded and became dilapidated, and all that remained of some of them was their charred frames. Pain squeezed Kartu's heart” (Szécsi, 1988).

In the tale Birds on the Golden Violin, anger surges into the members of the tribe when Hanidzsa leaves them: "Dzsaharla broke into mourning song, scattering ashes to the winds, wailing; it was her way of burying Hanidzsa who from this moment was dead for her tribe. [...] If she comes back, we'll bring justice to her according to our laws" (Szécsi, 1996). Hanidzsa's heart is also full of anger toward her people: "My heart is aching and is so full of bitterness that the ground would vomit me up if I were to die right now" (Szécsi, 1996).

Anger towards a father also occurs in the tale Radazana's Curse, when Szóberjáni tells his poor and orphan love, Radazana, that he is getting married and his father has chosen a wife for him, and the elders' word is law - he must obey. The son's wife humiliates the orphan girl, so Szóberjáni therefore beats his new wife; he hates not only his father but also his wife (Szécsi, 1988).

\section{Misery}

Misery is a recurring motif in the tales, which can occur in two forms: either Gypsies make each other miserable or strangers make Gypsies miserable.

In the tale The Mysterious Szalizáti, the protagonist suffers because he only loves himself and has committed many crimes against his people in the belief that it would make him happy (Szécsi 1988). In the tale The Orphan Radazána, the protagonist is abducted and taken to the king, who forces her into marriage. She is unhappy with her husband and suffers enormously. 
One day, a Gypsy caravan comes to the king to seek his help, because they have suffered much: "Succour my people, because we've been forced from our home by the great river, where we lived in peace. Our tents were robbed, and we have been turned into paupers" (Szécsi, 1988).

Misery caused by strangers also occurs in the tale Birds on the Golden Violin: "Cruel men attacked us and killed my people. Who knows why they did so, as we haven't sinned great sins. They beheaded our children, mutilated our women, and stabbed most of our men in sleep, they thus could not even defend themselves" (Szécsi, 1966).

The third type of the motif of misery can be found in the tale Doja, the Gypsy Fairy: Gypsies were greedy and did not appreciate the wealth they had in Gypsy Land, they therefore have to wander until they find one another again and expect Doja, the Gypsy fairy, to return to them and to help them in their hour of need (Szécsi 1988). In the tale Radazana's Curse, the members of her tribe have made the orphan Gypsy girl's life miserable, even robbing her; she therefore curses her thieving Gypsy people: "I want you to scatter to all the winds without ever having a night's peace. You shall wander as violated as I walked amongst you, Karadana said. Karadana lived for 170 more years, but her ghost has haunted Gypsies in the form of rows and fights to this very day. And in the form of their attitude to separate themselves from people around them" (Szécsi, 1988).

\section{Conclusion}

As can be seen, the analysed tales bear within them the marks of Roma culture; they thus bring their readers closer to Roma culture and help explain Roma behaviour patterns. The tales help their readers to acquire a better understanding of the Roma way of life, the reasons for their wandering and persecution, the differences between the functions of Roma men and women, and Romani law binding the Roma.

The persecution of Gypsies occurs frequently in the tales, murders are often committed, and not all the tales have a happy ending. Although the characters of the tales long for their home country, they feel safe distanced from the majority, since whenever they associate with "strangers" God punishes them. However, Gypsies reach out to the poor, people in need of help, and the socially excluded with compassion and respect "outliers" in spite of their mistrust towards and fear of strangers.

The king of the Gypsies, the voivode, is usually the one in the tales who has special abilities; he decides on important matters and pays particular attention to having Gypsy law respected by all. 
Magical practices and superstitions are an integral part of the tales. Numerous references to the conditions for the Gypsies' happiness and the causes of their suffering can be found in the tales of the two volumes. Faith in God, idolatry and Gypsy law are the three main components in the tales that determine the (Gypsy) characters' happiness or misery. Gypsy women feel a great deference towards men and value them highly. They desire happiness and understanding. If a woman violates Gypsy law, her punishment is death. The moral of the tales is that no one can ignore their origin, and they will find happiness only if they cease mixing with members of other tribes and choose a spouse from their own tribe.

Magda Szécsi's literary tales merit our attention, as they take a sensible approach to reflecting the relationships between Roma and non-Roma people. The violin is an important cultural symbol and a symbol of self-determination in the tales under discussion; the motif of the violin thus carries different meanings. In the tale Birds on the Golden Violin, the symbolic nature of the musical instrument is a thread woven through the whole story, and it can be interpreted as the symbol of suffering, happiness and misery. Hanidzsa refuses to submit to the laws of her people and takes to the road to discover her true identity; the tale is about transitional phases in the life of a subject of a rite of passage. Hanidzsa's path is the symbol of detaching herself from her tribe. The violin is her indispensable companion while making her way in life, which is associated with transcendence and symbolizes the celestial sphere. The magical golden violin is a musical instrument with miraculous properties in the literary tale, which is the guardian of two generations of female family members, i.e. the mother and daughter, and only the very select can enjoy such a gift. It symbolizes the Gypsies' souls, their "fairy godmother", fire-fairy and God's flower. It represents the Gypsies' past and present, their entire history. The "birds" in the title can be interpreted as a metaphor for the Gypsies, and the attribute "golden" may refer to the transcendental sphere, as the violin appears at the time of Hanidzsa's birth and vanishes at the time of her death: it was created and disappears in the same spot. Hanidzsa escapes into the unknown, looking for a way to her people, and wants to meet new, strange people; she can therefore be a symbol for knowledge acquired through experience. It is stated in the study collection Hiedelmek, hagyományok, babonák a világ minden tájáról edited by Margit Rosta and Attila Rábai that the violin is attributed to Saint David as his instrument. Legend has it that Saint David played the violin on the moon and Saint Cecilia danced to his music. The violin and its bow together symbolize the ideal pairing of a man and woman (Rosta \& Rábai, 2007, p. 231). In this regard, the violin becomes a supernatural instrument again: the bow does not appear in the tale, and usually the wind plucks the strings. Where it is assumed that the bow symbolizes a man, a clearer picture emerges: Liellera is genuinely in love with her 
husband, and the object of extraordinary power does not appear to her. The golden violin makes its first appearance when their daughter, Hanidzsa, is born. She defies the wishes of her tribe, because she refuses to marry a man she does not love; she stipulates (and her daughter will also stipulate) that she is willing to marry only once the bird of paradise appears in her dreams. The bird appears in her dreams, and she later gives birth to her daughter. The violin now belongs to her daughter, but after a bird also appears in Razsinnáta's dream, the violin breaks apart into little pieces and vanishes. Both women need this miraculous guardian as long as they find happiness, fall in love, and Razsinnáta finds her way back to her tribe. The violin without its bow can be interpreted as a metaphor for women's vulnerability. The music and notes of the violin are also meaningful: Wonderful violin music can be heard when Hanidzsa is born or when Razsinnáta returns to her tribe, but it just whirrs while Hanidzsa is seeking the right path or when it disappears. It is therefore the symbol of the heart and emotions as well. Reading Roma literature - in this case, Roma tales - enables us to increase our awareness of Roma culture, but Roma literary tales not only reflect the values of the Roma people's culture but also contain elements and motifs that are completely different from those in European tales. The details of everyday life and the modern world, and relationships between Roma and non-Roma people are interwoven with the fabled thread and echo in the tales under discussion. The authors' opinions and positions taken on various issues are often evident from literary tales. It may be the very reason for the relevance of the motif of cruelty in the tales, which can be interpreted as God's punishment, meaning that the characters in the tales can remain faithful to their tribe only if they do not mix with strangers.

Pupils should read tales that are able to teach them about Roma traditions, values, historical events and echo current societal issues. This objective is feasible with well-chosen methodological tools. The objectives do not include the methodological analysis of tales but the discussion of a few elements. The main aim is, to the effect of reading Roma tales, for individuals to acquire competencies that enable them to better understand the differences between the majority society and minority groups, to build tolerance in their lives, and to learn to have respect for the traditions, culture and history of other groups. It is indispensable to develop certain competencies of pupils in the field of ethnology to enable them to adopt an open attitude to different cultures and others from different cultures. School education provides the best framework for pupils to acquire these competencies. 


\section{Works cited:}

Bálint, P., 2014. Archaikus alakztatok a népmesében Jakab István cigány mesemondó (a késleltető halmozás mestere) - Archaic Images in Folk Tales the Tales of István Jakab, Gypsy Tale Teller (the master of delayed accumulation). Debrecen: Didakt Kft.

Boreczky, Á. - Földes, P. - Gyebnár V. - Solymosi K., 2007. Családok távolból és félközelböl (Families from a distance and from semi-close). Budapest: Gondolat Kiadó.

Giddens, A. \& Sutton, W.P. 2009. Sociology. Cambridge: Polity Press.

Giddens, A., 2000. Szociológia (Sociology). Budapest: Osiris Kiadó.

Károlyi, J. 2009. “...hanem az életnek.. (...but for life...).” In: Boreczky Ágnes (eds.). Cigányokról - másképpen. Budapest: Gondolat Könyvkiadó, p. 146.

Kozma, T., 2001. Bevezetés a nevelésszociológiába (Introduction to the Sociology of Education). Budapest: Nemzeti Tankönyvkiadó.

Krippendorff, K., 1995. A tartalomelemzés módszertanának alapjai (Content Analysis: an Introduction to its Methodology). Budapest: Balassi Kiadó.

Móré, M. 2010. “A tartalomelemzés, mint a szakdolgozatírásban alkalmazható kutatási módszer (Content Analysis as a Research Method Applicable for Thesis Writing).” In: Kovácsné Bakosi Éva (eds.). Társadalomtudományi tanulmányok III. DEGYFK, pp. 47-64.

Réger, Z. 1990. Utak a nyelvhez (Ways to Language). Budapest: Akadémia Kiadó.

Rosta, M. - Rábai, A., 2007. Hiedelmek, hagyományok, babonák a világ minden tájáról (Beliefs, traditions, and superstitions from around the world'). Budapest.

Szécsi, M., 1988. Az aranyhalas lószem tükre (Mirror of the Horse Eye with the Gold Fish). Budapest: HungariaSport.

Szécsi, M., 1996. Madarak aranyhegedün (Birds on the Golden Violin). Budapest: Omnis Fabula.

Tóthová, G. 2012. "Roma tradíciók, babonák (Roma Traditions, Superstitions).” In: Tibor Žilka and Anna Sándorová and Zoltán Németh (eds.). Cesty k vede-Utak a tudományhoz. Nitra: UKF, pp. 227238.

Tóthová, G. 2014. “Roma babonák (Roma Superstitions).” In: Irena Lehocká and Károly Presinszky, (eds.). Cesty $k$ vede-Utak a tudományhoz III. Nitra: UKF, pp. 71-81.

Tóthová, G. 2018. “The Study of Magda Szécsi’s Tales in the Mirror of Primary Socialisation.” In: Language, Individual \& Society: Journal of International Scientific Publications, vol. 12, no. 2 [cit. 2018-12-28], pp. 173-180. Available at:

$<$ https://www.scientific-publications.net/get/1000032/1537874457775811.pdf>. 


\section{Gizela Tóthová}

Institute of Hungarian Linguistics and Literary Science

Faculty of Central European Studies

Constantine the Philosopher University in Nitra

Dražovská cesta 4

94974 Nitra

Slovakia

tothova.gizela@gmail.com 